\title{
IL-10 Promoter Polymorphism Distribution among HBsAg-Reactive and HBsAg-Nonreactive Blood Donors
}

\author{
Rahmat Azhari Kemal, ${ }^{1}$ Arfianti, ${ }^{1}$ Reni Oktora, ${ }^{2}$ Bebe Gani, ${ }^{2}$ Fauzia Andrini Djojosugito, ${ }^{3}$ Winarto ${ }^{4}$ \\ ${ }^{1}$ Department of Medical Biology, Faculty of Medicine, University of Riau, Indonesia, ${ }^{2}$ Blood Transfusion Unit, \\ Indonesian Red Cross Pekanbaru, Riau, Indonesia, ${ }^{3}$ Department of Microbiology, Faculty of Medicine, \\ University of Riau, Indonesia, ${ }^{4}$ Department of Histology, Faculty of Medicine, University of Riau, Indonesia
}

\begin{abstract}
Hepatitis B surface antigen (HBsAg) serves as a serological marker for Hepatitis B virus (HBV) infection. People with HBV asymptomatic infection might readily donate blood due to the lack of clinical manifestations. Host immunity contributes to susceptibility and progression of infection. A polymorphism in IL-10 gene promoter, rs1800896, might contribute to host immunity. This study was conducted on May 2019-January 2020 in Faculty of Medicine, University of Riau on 70 blood samples from donors in the Indonesian Red Cross Pekanbaru. Out of these samples, 35 were reactive for HBsAg and 35 donors were nonreactive. Genotyping of rs1800896 was conducted using Amplification Refractory Mutation System (ARMS-PCR). In total, The distribution of AA (74.3\%), AG (24.3\%), and GG (1.4\%) genotypes revealed in this study seemed to be similar to genotype distribution among East and South-East Asian populations. While no significant difference was observed on age mean and gender distribution, a significant difference was identified in genotype distribution between HBsAg status (p-value 0.028) with the percentage of AA genotype was higher among HBsAg-nonreactive donors (85.7\%) compared to reactive donors (62.9\%). More studies should be conducted to characterize HBsAg-reactive blood donors, including the donor characteristics and the viral genotypes. Such studies should contribute to hepatitis B management in Indonesia.
\end{abstract}

Key words: Blood donor, hepatitis, HBsAg, IL-10, polymorphism

\section{Distribusi Polimorfisme Promoter IL-10 pada Donor Darah dengan HBsAg Reaktif dan Nonreaktif di Pekanbaru}

\begin{abstract}
Abstrak
Hepatitis B surface antigen (HBsAg) merupakan penanda serologis infeksi virus hepatitis B (HBV). Individu dengan infeksi HBV asimptomatik dapat melakukan donasi darah karena tidak ada gejala klinis. Imunitas inang berkontribusi pada kerentanan dan perkembangan infeksi. Polimorfisme pada promoter gen IL-10, rs1800896, dapat berkontribusi pada imunitas inang. Penelitian dilakukan pada bulan Mei 2019-Januari 2020 di Fakultas Kedokteran Universitas Riau. Sampel diambil adalah 70 darah donor dari Palang Merah Indonesia Pekanbaru, 35 sampel reaktif HBsAg dan 35 sampel nonreaktif. Genotipe rs1800896 dilihat berdasar atas amplification refractory mutation system (ARMS-PCR). Pada populasi studi ini, distribusi genotipe AA (74.3\%), AG (24.3\%), dan GG (1.4\%) sesuai populasi Asia Timur dan Tenggara. Walaupun tidak terdapat perbedaan pada rerata umur dan distribusi jenis kelamin, penelitian ini menemukan perbedaan signifikan pada distribusi genotipe antar kelompok status HBsAg ( $p=0.028)$, yaitu persentase genotipe AA lebih tinggi pada kelompok donor dengan HBsAg nonreaktif $(85.7 \%)$ dibanding dengan kelompok reaktif (62.9\%). Studi lebih lanjut perlu dilakukan untuk karakterisasi donor darah dengan HBsAg reaktif, termasuk gneotipe donor dan virus. Informasi tersebut diharapkan dapat bermanfaat pada manajemen hepatitis B di Indonesia.
\end{abstract}

Kata kunci: Donor darah, hepatitis, HBsAg, IL-10, polimorfisme

Corresponding Author: Rahmat Azhari Kemal, Department of Medical Biology, Faculty of Medicine, University of Riau, Jalan Diponegoro No.1, Suka Mulia, Pekanbaru, Riau 28133, Indonesia, Email: rahmat.azharikemal@lecturer.unri.ac.id 


\section{Introduction}

Hepatitis B surface antigen (HBsAg) is a serum biomarker for hepatitis B virus (HBV) infection. In 2013, the prevalence of HBsAg seropositivity in Indonesia was 7.1\%, thus making Indonesia categorized as an intermediate endemic area for hepatitis B. ${ }^{1}$ Hepatitis B virus infection has various clinical manifestations, starting from asymptomatic to hepatocarcinoma. People with asymptomatic HBV infection might be unaware of their status, thus readily donate blood. Therefore, the Indonesian Red Cross (IRC) screen for HBsAg among their donors to minimize the horizontal transmission of this disease. ${ }^{2}$

The clinical outcome of $\mathrm{HBV}$ infection is affected by the immune response formed by host-pathogen interactions. Host immunity contributes to the susceptibility and progression of infection. ${ }^{3}$ An anti-inflammatory cytokine, IL-10, has already been shown to play a role in chronic hepatitis $\mathrm{B}$ pathogenesis. Literature showed that chronic hepatitis B patients had a higher IL-10 level compared to healthy controls. ${ }^{4}$ An A/G polymorphism located in the -1082 site of $I L-10$ gene promoter, rs1800896, affects the gene's transcription level and, thus, IL-10 level. A lipopolysaccharide-induced ex vivo IL10 production shows that the $-1082 \mathrm{~A}$ allele is associated with a lower IL-10 production, and the functional association is allele-dose dependent. ${ }^{5}$ Several studies have been conducted to analyze the association between the rs1800896 polymorphism and HBV infection. ${ }^{6-7}$ Therefore, this study analyzed the association between rs1800896 genotype and HBsAg status among blood donors in IRC Pekanbaru, Indonesia.

\section{Methods}

The minimum sample size was calculated using the case-control study formula. Based on the proportion and cumulative odds ratio from literature, ${ }^{8}$ the minimum sample size required was 35 people for each group. This study was conducted from May 2019 to January 2020. Sampling was conducted on donated blood and the analysis of the blood was performed using the chemiluminescent immunoassay (CLIA) at the Blood Transfusion Unit of the Indonesian Red Cross (IRC) Pekanbaru. All HIV reactive blood samples were excluded. There were a total of 70 blood samples collected comprising of $35 \mathrm{HBsAg}$ reactive samples and $35 \mathrm{HBsAg}$ non-reactive samples. Demographical data of age and gender were retrieved. This study has been approved by the Ethical Review Board for Medicine and Health Research, Faculty of Medicine, University of Riau with the issuance of the ethical clearance No: 0.68/UN/19.5.1.1.8/UEPKK/2019.

Molecular analysis was conducted at the Integrated Research Lab of the Faculty of Medicine, University of Riau, Indonesia. The genomic DNA was isolated from blood fraction using the Wizard DNA Purification Kit (Promega, Madison, WI, USA) according to the protocol with slight modifications. After initial cell lysis, the supernatant was discarded and an additional cell lysis step with $450 \mu \mathrm{L}$ Cell Lysis Solution was conducted. DNA isolates were used as the template for $I L-10$ gene promoter polymorphism analysis (rs1800896; -1082A>G) by amplification-refractory mutation system (ARMS) PCR. The PCR was conducted to identify A-to-G polymorphism at -1082 position. Primer sequences used were as described in Perrey et al. ${ }^{9}$ PCR mix composition was adapted from Perrey et al. $^{9}$ with slight adjustment. PCR mix composition (final concentration) was 1X GoTaq Green Master Mix, $2.5 \mu \mathrm{M}$ of each ARMS primer, and $0.5 \mu \mathrm{M}$ of each internal control primer. PCR condition was adapted from Perrey et al., ${ }^{8}$ which consisted of initial denaturation (1 minute, $95^{\circ} \mathrm{C}$ ), 10 cycles of amplification I (denaturation $95^{\circ} \mathrm{C}, 15 \mathrm{sec}$; annealing $65^{\circ} \mathrm{C}, 50 \mathrm{sec}$; extension $\left.72^{\circ} \mathrm{C}, 40 \mathrm{sec}\right), 20$ cycles of amplification II (denaturation $95^{\circ} \mathrm{C}, 20 \mathrm{sec}$; annealing $59^{\circ} \mathrm{C}, 50$ sec; extension $72^{\circ} \mathrm{C}, 50 \mathrm{sec}$ ) and final extension $\left(72{ }^{\circ} \mathrm{C}, 5\right.$ minutes). ${ }^{9}$ Ten $\mu \mathrm{L}$ of PCR product was analyzed by electrophoresis on $2 \%$ agarose, $80 \mathrm{~V}$, 35 minutes. Allele and genotype was concluded based on the band pattern.

Statistical analyses were conducted on age, gender, and genotype distribution (SPSS software version 24). The mean age between HBsAg status was analyzed using the t-test, while gender distribution between HBsAg status was analyzed using the chi-square test. The chi-square test was conducted for genotype distribution between HBsAg status. a p-value of $<0.05$ was considered statistically significant.

\section{Results}

This study included 70 blood donors, which consisted of 35 (50\%) HBsAg-reactive samples and 35 (50\%) HBsAg-nonreactive samples. Table 2 presented the demographical data of sampled blood donors in IRC Pekanbaru, Indonesia. No significant difference was observed in mean 
Table 1 Primers Used in This Study ${ }^{9}$

\begin{tabular}{lc}
\hline \multicolumn{1}{c}{ Sequence } & Amplicon (bp) \\
\hline (-1082) & \\
A 5'- ACTACTAAGGCTTCTTTGGGAA- 3' & 259 \\
G 5'- CTACTAAGGCTTCTTTGGGAG 3' & \\
Generic 5'- CAGTGCCAACTGAGAATTTGG 3' & \\
Internal control & 429 \\
HGHF 5'- GCCTTCCCAACCATTCCCTTA 3' \\
HGHR 5'- TCACGGATTTCTGTTGTGTTTC 3'
\end{tabular}

Table 2 Demographical Data of Blood Donors in IRC Pekanbaru, Indonesia

\begin{tabular}{lcccc}
\multicolumn{1}{c}{ Variable } & $\begin{array}{c}\text { HBsAg reactive } \\
(\mathbf{n = 3 5 )}\end{array}$ & $\begin{array}{c}\text { HBsAg nonreactive } \\
(\mathbf{n = 3 5 )}\end{array}$ & Total & p-value \\
\hline $\begin{array}{l}\text { Mean age } \pm \text { SD, year } \\
\text { Gender }\end{array}$ & $39.54 \pm 10.88$ & $37.26 \pm 10.79$ & $38.4 \pm 10.84$ & 0.381 \\
Male & $27(77.1)$ & $25(71.4)$ & $52(74.3)$ & 0.584 \\
Female & $8(22.9)$ & $10(28.6)$ & $18(25.7)$ & \\
\hline
\end{tabular}

age and gender distribution between different HBsAg status. Table 3 listed the rs1800896 genotypes and alleles among blood donors in IRC Pekanbaru based on their HBsAg status. This genotype distribution follows the HardyWeinberg equilibrium $\left(p^{2}+2 p q+q^{2}=1\right)$, with $p$ as the frequency of allele $\mathrm{A}, \mathrm{q}$ as the frequency of allele $\mathrm{G}, \mathrm{p}^{2}$ as the frequency of genotype AA, $2 \mathrm{pq}$ as the frequency of genotype $\mathrm{AG}$, and $\mathrm{q}^{2}$ as the frequency of genotype GG. Based on the result of the chi-square analysis, there was a statistical difference in genotype distribution based on HBsAg status among blood donors in IRC Pekanbaru (Table 3).

\section{Discussion}

This study performed genotyping of 70 blood donors for rs1800896 polymorphism. The genotype distribution in total study population and both HBsAg status groups followed the Hardy-Weinberg equilibrium. The low frequency of GG genotype is typical for East and Southeast

Table 3 Distribution of rs1800896 Polymorphism among Blood Donors in IRC Pekanbaru, Indonesia

\begin{tabular}{cccc}
\hline \multicolumn{1}{c}{ Variable } & $\begin{array}{c}\text { HBsAg reactive } \\
\text { n (\%) }\end{array}$ & $\begin{array}{c}\text { HBsAg nonreactive } \\
\text { n (\%) }\end{array}$ & $\begin{array}{c}\text { Total } \\
\mathbf{n}(\%)\end{array}$ \\
\hline rs1800896 genotype & & & \\
AA & $22(62.9)$ & $30(85.7)$ & $52(74.3)$ \\
AG & $13(37.1)$ & $4(11.5)$ & $17(24.3)$ \\
GG & $0(0.00)$ & $1(2.8)$ & $1(1.4)$ \\
rs1800896 allele & & & \\
A & $57(81.0)$ & $64(91.0)$ & $121(86.4)$ \\
G & $13(19.0)$ & $6(9.0)$ & $19(13.6)$ \\
\hline
\end{tabular}


RA Kemal, et al: IL-10 Promoter Polymorphism Distribution among HBsAg-Reactive and HBsAg-Nonreactive Blood Donors

Table 4 Comparison of rs1800896 Polymorphism Distribution among Blood Donors in IRC Pekanbaru, Indonesia

\begin{tabular}{lccc}
\hline \multicolumn{1}{c}{ Variable } & $\begin{array}{c}\text { HBsAg reactive } \\
\text { n (\%) }\end{array}$ & $\begin{array}{c}\text { HBsAg nonreactive } \\
\text { n (\%) }\end{array}$ & p-value \\
\hline rs1800896 genotype & & & 0.028 \\
AA & $22(62.9)$ & $30(85.7)$ & \\
AG / GG & $13(37.1)$ & $5(14.3)$ & 0.084 \\
rs1800896 allele & & & \\
A & $57(81.0)$ & $64(91.0)$ & \\
G & $13(19.0)$ & $6(9.0)$ & \\
\hline
\end{tabular}

Table 5 Comparison of rs 1800896 Genotype Distribution among Several Populations ${ }^{10}$

\begin{tabular}{|c|c|c|c|c|c|}
\hline Region & Population & Sample size & AA (\%) & AG (\%) & GG (\%) \\
\hline \multirow[t]{10}{*}{ South-East Asia } & This study & 70 & 74.3 & 24.3 & 1.4 \\
\hline & Malaysia & & & & \\
\hline & Batek & 25 & 84.0 & 16.0 & 0.0 \\
\hline & Kensiu & 36 & 86.1 & 13.9 & 0.0 \\
\hline & Semai & 42 & 81.0 & 19.0 & 0.0 \\
\hline & Orang Kanaq & 11 & 0.0 & 100.0 & 0.0 \\
\hline & Lanoh & 24 & 88.0 & 12.0 & 0.0 \\
\hline & Che Wong & 26 & 50.0 & 46.2 & 3.8 \\
\hline & Singapore & & & & \\
\hline & Chinese & 83 & 95.1 & 4.9 & 0.0 \\
\hline \multirow[t]{11}{*}{ East Asia } & Hong Kong & & & & \\
\hline & Chinese & 100 & 89.0 & 10.0 & 1.0 \\
\hline & Taiwan & & & & \\
\hline & Ami & 50 & 96.0 & 2.0 & 2.0 \\
\hline & Atayal & 50 & 88.0 & 12.0 & 0.0 \\
\hline & Hakka & 45 & 93.0 & 7.0 & 0.0 \\
\hline & Yami & 40 & 95.0 & 5.0 & 0.0 \\
\hline & Tsou & 50 & 98.0 & 2.0 & 0.0 \\
\hline & Minnan & 50 & 94.0 & 6.0 & 0.0 \\
\hline & South Korea & & & & \\
\hline & Minnan & 57 & 74.0 & 26.0 & 0.0 \\
\hline \multirow[t]{3}{*}{ South Asia } & India & & & & \\
\hline & North & 130 & 59.0 & 36.0 & 2.0 \\
\hline & Delhi & 34 & 58.1 & 37.6 & 4.3 \\
\hline \multirow[t]{3}{*}{ West Asia } & Iraq & & & & \\
\hline & Arab & 224 & 40.8 & 41.3 & 17.9 \\
\hline & Jordan & 118 & 42.5 & 51.7 & 5.9 \\
\hline \multirow[t]{2}{*}{ Africa } & South Africa & & & & \\
\hline & Zulu (Natal Region) & 86 & 33.4 & 57.1 & 9.5 \\
\hline Europe & Netherlands & 107 & 29.0 & 44.0 & 27.0 \\
\hline \multirow[t]{2}{*}{ South America } & Argentina & & & & \\
\hline & Buenos Aires & 54 & 25.9 & 48.1 & 25.90 \\
\hline
\end{tabular}


Asia populations (Table 4). ${ }^{10}$

The genotype distribution was significantly different statistically between different HBsAg status among blood donors in IRC Pekanbaru (Table 2). HBsAg-nonreactive donors had a higher frequency of AA genotypes. The metaanalysis suggested a significant association between genotype AA of the rs1800896 polymorphism, which has a lower risk of chronic HBV infection and a higher level of HBV self-clearance following acute infection. ${ }^{11}$ The $-1082 \mathrm{~A}$ allele has a reduced IL-10 level in an allele-dose dependent manner, thus individual with homozygous AA genotype has the lowest IL-10 level. ${ }^{5}$ In a persistent viral infection, IL-10 suppresses dendritic cell antigenic presentation capacity. ${ }^{12}$ Therefore, theoretically, a lower IL10 level in individuals with AA genotype might contribute to the lower risk of HBV persistent infection marked by the HBsAg seroreactivity.

There were several limitations to our study because data on the types of donor such as voluntary/replacement or first-time/multiple donors were not collected. Although HIVreactive samples were excluded, HCV and syphilis screening results were not collected in this study. However, due to the lower prevalence of HCV and syphilis in Indonesian blood donors, namely $0.41 \%$ and $0.77 \%$ respectively, ${ }^{2}$ these co-infections would not significantly biased the results of this study. Future studies should be conducted to analyze rs1800896 polymorphism among hepatitis B patients and various serum biomarkers, especially serum IL-10.

\section{Acknowledgment}

This study was funded by Faculty of Medicine University of Riau under Penelitian Dosen Pemula scheme (No. B/59/UN19.5.1.1.8/ PT.01.05/ UPPM/2019).

\section{References}

1. Muljono DH. Epidemiology of hepatitis B and $\mathrm{C}$ in Republic of Indonesia. Euroasian J Hepatogastroenterol. 2017;7(1):55-9.

2. Center of Data and Information, Ministry of Health of the Republic of Indonesia. 2018. Pelayanan Darah di Indonesia. [cited
December 2018, 28]. Available from: http:// www.pusdatin.kemkes.go.id/article / view/18091000001/pelayanan-darah-diindonesia-2018.html.

3. Tuncbilek S, Aydin K, Hizel K. Vitamin D and tumor necrosis factor-alpha receptor gene polymorphisms in various hepatitis B clinical conditions in Turkey. Gastroenterology Res. 2013;6(5):185-90

4. Özgüler M, Akbulut HH, Akbulut A. Evaluation of interleukin-10 levels in patients diagnosed with chronic hepatitis. West Indian Med J. 2015;64(2):71-5.

5. Zeng L, Gu W, Chen K, Jiang D, Zhang L, Du D, Hu P, Liu Q Huang S, Jiang J. Clinical relevance of the interleukin 10 promoter polymorphisms in Chinese Han patients with major trauma: genetic association studies. Crit Care. 2009;13(6):R188.

6. Baghi SG, Alavia SM, Mehrnoush L, Salimi S. Impact of the IL-10 promoter gene polymorphisms in the severity of chronic hepatitis B infection. Hepat Mon. 2015;15(7):e28287

7. Saxena R, Chawla YK, Verma I, Kaur J. Association of interleukin-10 with hepatitis $B$ virus (HBV) mediated disease progression in Indian population. Indian J Med Res. 2014;139(5):737-45.

8. Sofian M, Kalantar E, Aghakhani A, Hosseini S, Banifazl M, Eslamifar A, et al. No correlation between interleukin-10 gene promoter polymorphisms and hepatitis $B$ virus infection outcome. Hepat Mon. 2013;13(5): e8803

9. Perrey C, Turner SJ, Pravica, V, etal.ARMS-PCR methodologies to determine IL-10, TNF- $\alpha$, TNF- $\beta$ and TGF- $\beta 1$ gene polymorphisms. Transpl Immunol. 1999;7:127-8.

10. Gonzalez-Galarza FF, Takeshita LY, Santos EJ, et al. Allele frequency net 2015 update: new features for HLA epitopes, KIR and disease and HLA adverse drug reaction associations. Nucleic Acids Res. 2015;43:D784-8.

11. Shu C, Wang J, He Y, et al. Effects of interleukin 10 polymorphisms on the development of hepatitis B virus infection: a systematic review and meta-analysis. Int J Clin Exp Med. 2015;8(8):12028-40.

12. Rojas JM, Avia M, Martín V, Sevilla N. IL-10: a multifunctional cytokine in viral infections. J Immunol Res. 2017;2017:6104054. 